\title{
PENGARUH KONSENTRASI ASAM ASETAT TERHADAP KARAKTERISTIK FISIKOKIMIA TEPUNG IKAN DARI DAGING MERAH IKAN TUNA
}

\author{
Dian Fadila Sahril*, Vanessa N J Lekahena** \\ *Mahasiswa FAPERTA UMMU-Ternate, e-mail: - \\ **Staf Pengajar FAPERTA UMMU-Ternate, e-mail: enchalekahena@yahoo.com
}

\begin{abstract}
ABSTRAK
Daging merah ikan tuna adalah lapisan daging ikan yang berpigmen kemerahan yang mengandung mioglobin dan hemoglobin yang merupakan senyawa bersifat peroksidan, sehingga menyebabkan mudahnya terjadi ketengikan pada produk itu sendiri dan untuk itu perlu dilakukan prores pengolahan yang bertujuan untuk meningkatkan nilai ekonomis dan daya awetnya. Penelitian ini untuk mengetahui pengaruh konsentrasi asam asetat sebagai media perebusan terhadap karakteristik fisikokimia tepung ikan dari daging merah ikan tuna untuk menentukan konsentrasi optimum asam asetat dalam pembuatan tepung ikan dari daging merah ikan tuna. Manfaatnya adalah memimalkan limbah hasil sampingan pengolahan tuna loin dalam bentuk diversifikasi produk olahan berupa pembuatan tepung ikan dari daging merah ikan tuna dengan menggunakan variasi konsentrasi asam asetat untuk meningkatkan nilai ekonomis limbah dan menghasilkan produk dengan daya awet yang lama. Hasil penelitian menunjukkan bahwa perebusan daging merah ikan tuna menggunakan larutan asam asetat pada konsentrasi yang berbeda berpengaruh nyata terhadap derajat keasaman $(p H)$, kadar air, protein dan lemak serta derajat putih tepung ikan yang dihasilkan akan tetapi tidak berpengaruh nyata terhadap kadar abu. Daging merah ikan madidihang dapat dijadikan bahan baku dalam pembuatan tepung ikan dan dapat di simpan dalam waktu yang lama karena memenuhi syarat sebagai bahan baku kering dari karakteristik, fisik (derajat putih), kimia (proksimat), dan mikrobiologi (ALT).
\end{abstract}

Kata Kunci: Asam Asetat, Daging Merah, Karakteristik Fisikokimia

\section{PENDAHULUAN}

Indonesia merupakan salah satu negara pengekspor tuna terbesar di dunia. Ikan tuna pada umumnya diekspor dalam bentuk segar dan utuh disiangi, produk beku utuh disiangi, loin dan steak beku. Ikan tuna dan sejenis ikan dari keluarga scombridae banyak mengandung asam amino histidin yang mudah mengalami proses dekarboksilasi menjadi senyawa histamin.

Propinsi Maluku Utara merupakan salah satu wilayah yang memiliki penanganan ikan tuna terutama proses pembuatan tuna loin beku.
Tuna loin adalah suatu produk olahan hasil perikanan dengan bahan baku ikan tuna segar. Proses pengolahan ikan tuna loin menghasilkan limbah hasil olahan dalam bentuk limbah padat dan limbah cair. Limbah padat yang dihasilkan dari pengolahan ikan yaitu sebesar $20-30 \%$ dari total keseluran ikan, yaitu berupa tulang ikan, sirip, kulit dan daging merah.

Daging merah ikan tuna adalah lapisan daging ikan yang berpigmen kemerahan yang mengandung mioglobin serta kaya akan lemak, dengan diameter sel atau jaringan otot pada 
daging merah lebih kecil. Daging merah berada di sepanjang tubuh ikan pada bagian bawah kulit tubuh dengan jumlah bervariasi mulai $\pm 1-2 \%$ hingga $20 \%$ tergantung kadar lemak pada ikan. Daging merah pada ikan pelagis memungkinkan jenis ikan ini berenang pada kecepatan yang tetap untuk memperoleh makanan dan untuk bermigrasi (Learson dan Kaylor, 1990).

Komposisi gizi daging merah ikan tuna yaitu kadar air $67.03 \%$; protein $26.92 \%$; lemak 4.87\%; abu $0.97 \%$; Fe 32,11 mg atau sebesar $73,38 \%$ dari kadar Fe dengan kemampuan biovaibilitas yang tinggi. Karakteristik fisik daging merah ikan tuna adalah daya ikat air $8.37 \mathrm{~g}$ air/g dan kapasitas pemegangan air 8,11 g minyak/g. Hal ini menunjukkan bahwa daging merah ikan tuna dapat digunakan atau diaplikasikan dalam produk pangan. (Sánchez et al., 2011). Kandungan asam amino esensial arginin pada daging merah ikan tuna sekitar 7\% (Murray et al., 1991).

Warna merah pada daging ikan disebabkan kandungan hemoproteinnya tinggi yang tersusun atas protein miosin, globin dan struktur heme yang dikenal dengan nama mioglobin dan hemoglobin, merupakan senyawa bersifat peroksidan (Amrullah, 2000). Mioglobin dan hemoglobin merupakan jenis hemoprotein terbanyak dalam daging ikan yaitu sekitar $80 \%$, sedangkan pada daging merah ikan tuna kandungan mioglobin sekitar $3500 \mathrm{mg} / 100 \mathrm{~g}$ (Watanabe, 1990). Hal ini yang menyebabkan mudahnya terjadi ketengikan pada daging merah ikan tuna (Okada, 1990), dan untuk menghindari proses kemuduran mutu maka daging merah hasil pengolahan tuna loin dapat dimanfaatkan menjadi produk yang bernilai ekonomis tinggi misalnya dijadikan bahan dasar dalam pembuataan bakso, nugget, dan tepung ikan.

Tepung ikan adalah produk berkadar air rendah yang diperoleh dari penggilingan ikan. Tepung ikan yang bermutu baik harus mempunyai sifat-sifat sebagai berikut: butiranbutirannya harus seragam bebas dari sisa-sisa tulang, mata ikan dan benda asing, warna halus bersih, seragam, serta bau khas amis ikan.

Usaha pengolahan tepung ikan dapat dilakukan dengan tidak membutuhkan banyak biaya karena dapat dilakukan secara sederhana. Pembuatan tepung ikan secara umum dapat dilakukan menggunakan metode basah, kering dan penyulingan. Dari ketiga metode di atas, metode kering paling cocok dilakukan untuk industri kecil karena lebih sederhana dengan biaya rendah.

Proses perebusan menggunakan larutan asam dapat memutihkan daging ikan. Proses ekstraksi pada penelitian ini menggunakan larutan asam lemah yaitu asam asetat dengan variasi konsentrasi untuk mengetahui pengaruhnya terhadap karakteristik fisikokimia tepung ikan yang dihasilkan.

Penelitian ini bertujuan untuk mengetahui pengaruh konsentrasi asam asetat sebagai media ekstraksi terhadap karakteristik fisikokimia tepung ikan dari daging merah ikan tuna untuk menentukan konsentrasi optimum asam asetat dalam pembuatan tepung ikan dari daging merah ikan tuna. Manfaat dari penelitian ini adalah memimalkan limbah hasil sampingan pengolahan tuna loin dalam bentuk diversifikasi produk olahan berupa pembuatan tepung ikan dari daging merah ikan tuna dengan menggunakan variasi konsentrasi asam asetat untuk meningkatkan nilai ekonomis limbah dan menghasilkan produk dengan daya awet yang lama.

\section{METODE PENELITIAN}

Peralatan yang digunakan dalam penelitian ini adalah baskom, dandang pengukus, kompor, penggiling daging/grinder, pisau, talenan, oven, mesin penepungan (disc mill), seperangkat alat analisis proksimat, derajat putih (whiteness meter), pH meter, cawan petri, pipet tetes, erlemeyer, oven inkubator, dan alat tulis. Bahan yang digunakan yaitu daging merah ikan tuna, larutan asam asetat $\left(\mathrm{CH}_{3} \mathrm{COOH}\right) 25 \%$, air, bahan kimia untuk analisis proksimat dan mikrobiologi.

\section{Tahap persiapan bahan}

Bahan utama adalah daging merah ikan tuna yang sudah dibersihkan dari sisik, tulang, dan bagian lain yang tidak dipakai, serta larutan asam asetat $\left(\mathrm{CH}_{3} \mathrm{COOH}\right)$ konsentrasi $25 \%$, 
sebagai bahan yang digunakan untuk pembuatan larutan perebusan.

\section{Tahap pembuatan Tepung ikan}

Proses pembuatan tepung ikan melalui beberapa tahap yaitu: pencucian awal daging merah ikan tuna menggunakan air bersih untuk menghilangkan kotoran, lendir dan darah. Kemudian daging merah ikan tuna yang telah dibersihkan dilumatkan dengan menggunakan grinder hingga membentuk daging ikan lumat, selanjutnya dilakukan proses pencucian ke-2 dengan menggunakan larutan garam $2 \%$. Proses perebusan atau ekstraksi menggunakan larutan asam asetat dengan perlakuan sebagai berikut: $A_{0}$ (0\%, kontrol), $\mathrm{A}_{1}(5 \%), \mathrm{A}_{2}(10 \%)$ dan $\mathrm{A}_{3}(15 \%)$, pada suhu $80-100{ }^{\circ} \mathrm{C}$ selama \pm 20 menit. Daging ikan tuna yang sudah matang, disaring dan didinginkan lalu dikeringkan menggunakan oven pengering pada suhu $50{ }^{\circ} \mathrm{C}$ selama 24 jam hingga mencapai kadar air $<8 \%$. Tepung ikan yang telah kering selanjutnya di giling menggunakan disc mill dan diayak menggunakan saringan dengan mesh size 100.

Analisis yang dilakukan dalam penelitian ini meliputi: pH, kadar air (AOAC 925. 09 2005), abu (AOAC 941.12 2005), protein (AOAC 920.87 2005), lemak (AOAC 960. 39 2005), karbohidrat (metode by difference), analisis derajat putih dan analisis mikrobiologi penentuan angka lempeng total. Data pengamatan selanjutnya di analisis menggunakan Rancangan Acak Lengkap (RAL) atau Anova Single Factor (Steel dan Torrie, 1980) Jika data hasil pengujian berbeda nyata, maka dilakukan dengan uji lanjut menggunakan Beda Nyata Terkecil (BNT).

\section{HASIL DAN PEMBAHASAN}

\subsection{Analisis $\mathrm{pH}$}

Analisis pH merupakan derajat keasaman digunakan untuk menyatakan tingkat keasaman atau kebasaan suatu larutan. Pengujian $\mathrm{pH}$ terhadap tepung ikan untuk mengetahui pengaruh perebusan menggunakan larutan asam asetat pada konsentrasi yang berbeda terhadap $\mathrm{pH}$ tepung ikan yang dihasilkan. Nilai rerata $\mathrm{pH}$ tepung ikan (Gambar 1) menunjukkan peningkatan konsentrasi asam asetat menurunkan $\mathrm{pH}$ tepung ikan yang dihasilkan.

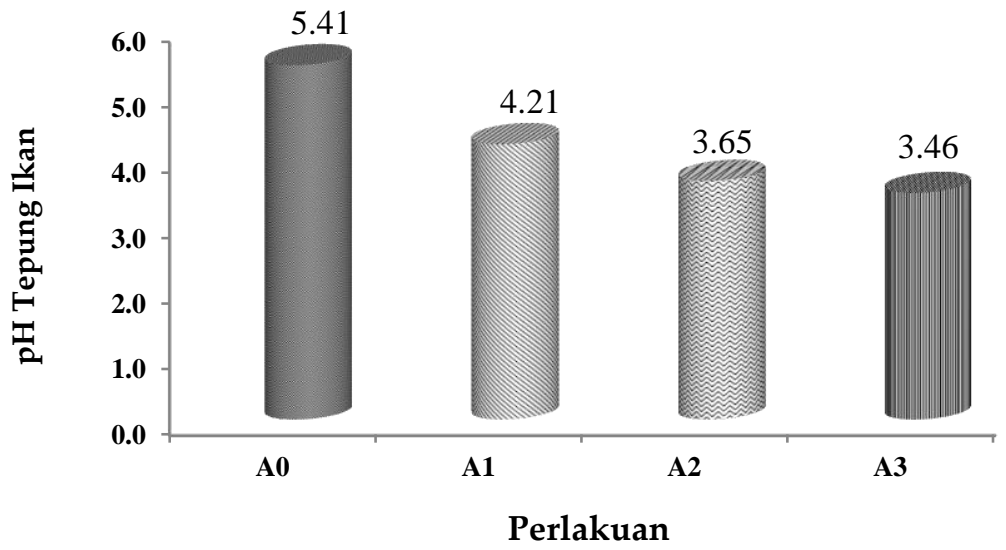

Gambar 1. Histogram Nilai Rerata Analisis pH Tepung Ikan

Berdasarkan hasil analisis sidik ragam derajat keasaman $(\mathrm{pH})$, menunjukkan bahwa konsentrasi larutan asam asetat memberikan pengaruh sangat nyata terhadap $\mathrm{pH}$ tepung ikan dari daging merah ikan madidihang pada $\rho>0.05$, artinya ada perlakuan yang pengaruhnya sangat menonjol dibandingkan dengan perlakuan lainnya terhadap $\mathrm{pH}$ tepung ikan. Hasil uji lanjut menggunakan BNT menunjukkan bahwa semua perlakuan memberikan pengaruh sangat nyata terhadap derajat keasaman tepung ikan. Hal ini diduga karena adanya pengaruh konsentrasi larutan asam asetat, makin besar konsentrasi asam asetat yang digunakan untuk perebusan 
makin menurun $\mathrm{pH}$ produk tepung ikan dan bersifat asam.

\subsection{Analisis Derajat Putih}

Derajat putih merupakan pengukuran yang umum dilakukan untuk menentukan kecerahan warna tepung, tepung umumnya memiliki tingkat kecerahan yang berbeda-beda (Hutching, 1999). Pengukuran derajat putih berada pada skala $0-100 \%$ yaitu mulai dari warna hitam $(0 \%)$ sampai dengan putih (100\%). Nilai derajat putih (Gambar 8) tertinggi pada perlakuan $\mathrm{A}_{1}(35.07 \%)$ sedangkan nilai terendah pada perlakuan $A_{0}$ $(\mathbf{2 6 . 9 0 \% )}$. Proses perebusan menggunakan asam asetat meningkatkan derajat putih tepung ikan yang dihasilkan, akan tetapi pada konsentrasi asam asetat tertentu derajat putihnya tepung yang dihasilkan tidak berbeda dengan sampel kontrol ( $\left.\mathbf{A}_{0}\right)$, hal tersebut terlihat pada perlakuan $A_{2}(10 \%)$ dan $A_{3}$ (15\%). Kelemahan penggunaan asam untuk hidrolisis protein adalah bentuknya warna kehitaman atau melamin yang terbentuk dari kandungan indol triptopan dengan aldehid yang berasal dari karbohidrat yang terdapat pada bahan (Johnson dan Paterson 1984).

Hasil analisis sidik ragam menunjukkan bahwa konsentrasi asam asetat berpengaruh nyata terhadap derajat putih tepung ikan dimana pada $\rho>0,05$, artinya ada perlakuan yang pengaruhnya sangat menonjol dibandingkan dengan perlakuan lainnya terhadap derajat putih tepung ikan. Hasil uji lanjut menggunakan BNT, menunjukkan bahwa semua perlakuan yang diberikan memberikan pengaruh yang sangat menonjol satu dengan yang lainnya terhadap derajat putih tepung ikan.
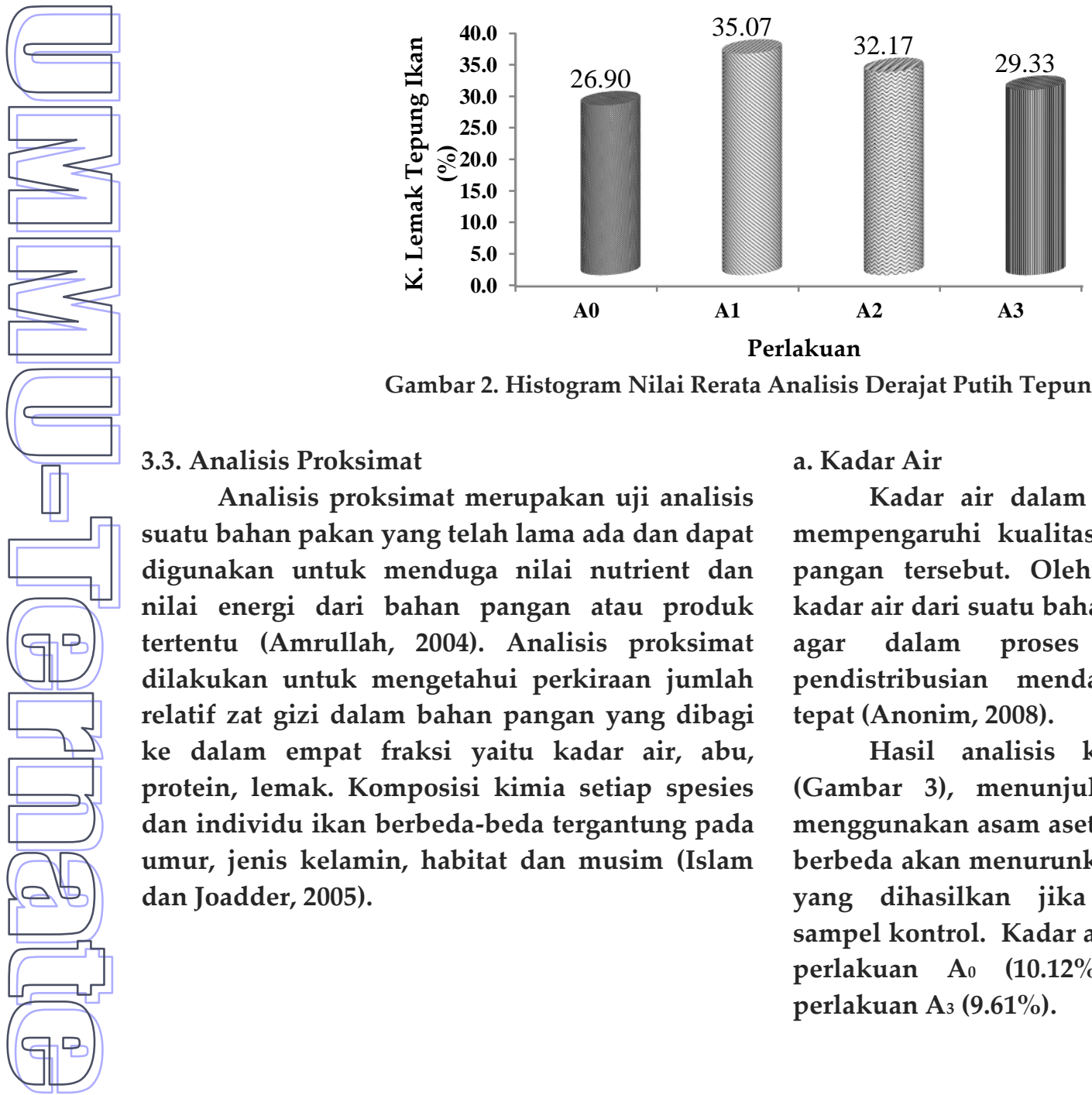

Gambar 2. Histogram Nilai Rerata Analisis Derajat Putih Tepung Ikan

\subsection{Analisis Proksimat}

Analisis proksimat merupakan uji analisis suatu bahan pakan yang telah lama ada dan dapat digunakan untuk menduga nilai nutrient dan nilai energi dari bahan pangan atau produk tertentu (Amrullah, 2004). Analisis proksimat dilakukan untuk mengetahui perkiraan jumlah relatif zat gizi dalam bahan pangan yang dibagi ke dalam empat fraksi yaitu kadar air, abu, protein, lemak. Komposisi kimia setiap spesies dan individu ikan berbeda-beda tergantung pada umur, jenis kelamin, habitat dan musim (Islam dan Joadder, 2005).

\section{a. Kadar Air}

Kadar air dalam bahan makanan sangat mempengaruhi kualitas dan daya simpan dari pangan tersebut. Oleh karena itu, penentuan kadar air dari suatu bahan pangan sangat penting agar dalam proses pengolahan maupun pendistribusian mendapat penanganan yang tepat (Anonim, 2008).

Hasil analisis kadar air tepung ikan (Gambar 3), menunjukkan bahwa perebusan menggunakan asam asetat pada konsentrasi yang berbeda akan menurunkan kadar air tepung ikan yang dihasilkan jika dibandingkan dengan sampel kontrol. Kadar air tertinggi terdapat pada perlakuan Ao $(\mathbf{1 0 . 1 2} \%)$ dan terendah pada perlakuan $\mathrm{A}_{3}$ (9.61\%). 


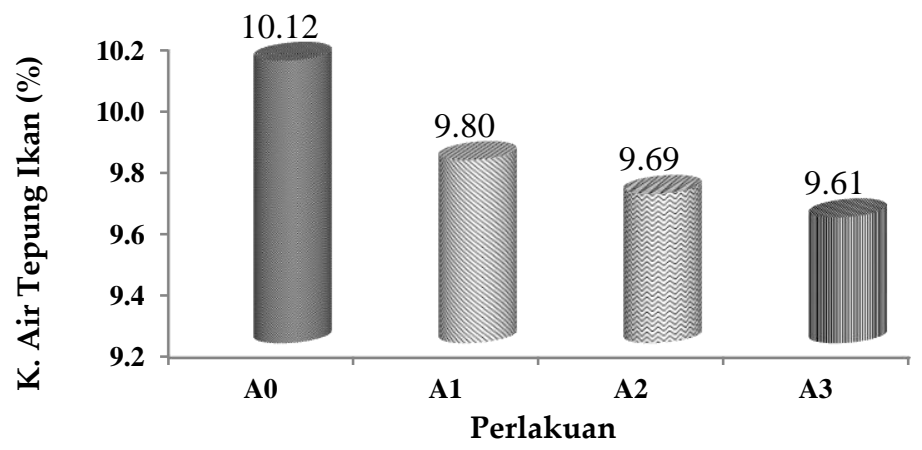

Gambar 3. Histogram Nilai Rerata Kadar Air Tepung Ikan

Proses perebusan menggunakan larutan asam asetat dapat menarik air keluar dari sel-sel jaringan daging ikan sehingga dapat menurunkan kadar air tepung ikan. Perebusan menggunakan larutan asam asetat menurunkan kemampuan pembentukan gel pada daging ikan, sehingga pada saat pengeringan mengakibatkan air mudah terlepas dari jaringan daging ikan. Kadar air tepung ikan yang berkualitas baik adalah $6-10 \%$, karena pada kadar air tersebut sulit terjadinya kerusakan akibat aktivitas mikroba (Kurnia dan Purwani, 2008). Kadar air tepung ikan yang dihasilkan pada penelitian ini memenuhi standar tepung ikan dengan kualitas terbaik yaitu pada kisaran $9.61-10.12 \%$

Hasil analisis sidik ragam kadar air $\rho>$ 0.05, menunjukkan konsentrasi larutan asam asetat berpengaruh nyata terhadap kadar air tepung ikan, artinya ada perlakuan yang pengaruhnya sangat menonjol dibandingkan dengan perlakuan lainnya terhadap kadar air tepung ikan. Hasil uji lanjut menggunakan BTN, menunjukkan bahwa semua perlakuan pada penelitian ini memiliki pengaruh yang sangat menonjol satu dengan perlakuan lainnya terhadap kadar air tepung ikan.

b. Kadar Abu

Kadar abu merupakan campuran dari komponen anorganik atau mineral yang terdapat pada suatu bahan pangan. Bahan pangan terdiri dari $96 \%$ bahan organik dan air, sedangkan sisa lainnya merupakan unsur-unsur mineral (Winarno, 1992). Nilai rerata kadar abu (Gambar 5), menunjukkan kadar abu tepung ikan mengalami perurunan seiring dengan meningkatnya konsentrasi larutan asam asetat yang digunakan untuk perebusan. Kadar abu tertinggi terdapat pada perlakuan $A_{0}(5.58 \%)$ sedangkan yang terendah pada perlakuan $\mathrm{A}_{3}$ (3.45\%). Hal tersebut menunjukkan bahwa larutan asam dapat menghidrolisis kandungan mineral yang terdapat dalam daging ikan, sehingga kadar abu yang terdapat pada tepung ikan mengalami penurunan.

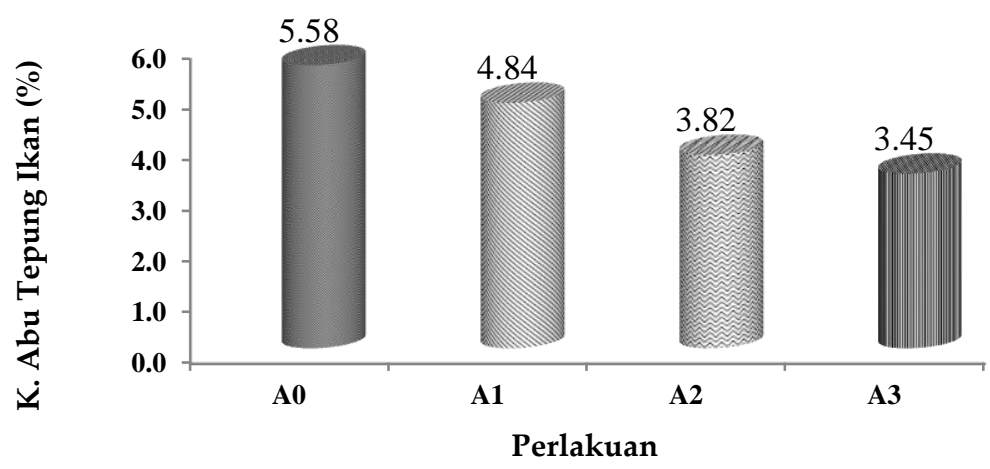

Gambar 4. Histogram Nilai Rerata Kadar Abu Tepung Ikan 
Hasil analisis sidik ragam kadar abu menunjukkan bahwa konsentrasi larutan asam asetat berpengaruh nyata terhadap kadar abu tepung ikan pada $\rho>0.05$, artinya ada perlakuan yang pengaruhnya sangat menonjol dibandingkan dengan perlakuan lainnya terhadap kadar abu tepung ikan. Hasil uji lanjut menggunakan BTN, menunjukkan bahwa semua perlakuan pada penelitian ini memiliki pengaruh yang sangat menonjol satu dengan perlakuan lainnya terhadap kadar abu tepung ikan.

c. Kadar Protein

Kadar protein merupakan salah satu kelompok bahan makronutrien yang dapat menghasilkan energi seperti halnya karbohidrat dan lemak, tetapi peran yang sangat penting adalah pembentukan biomolekul.

Hasil analisis kadar protein tepung ikan menunjukkan bahwa kadar protein tertinggi terdapat pada perlakuan $A_{0} \quad(81.46 \%)$ dan terendah pada perlakuan $A_{3}(79.832 \%)$. Dari hasil ini menunjukkan peningkatan konsentrasi asam asetat menurunkan kadar protein dari tepung ikan, hal ini disebabkan karena asam mampu menghidrolisis protein yang terkandung dalam daging ikan sehingga larut dalam larutan asam yang digunakan untuk proses perebusan. (Gambar 6).

Hasil analisis sidik ragam kadar protein menunjukkan bahwa ektrasi menggunakan larutan asam asetat berpengaruh sangat nyata terhadap kadar protein tepung ikan pada $\rho>0.05$. Artinya ada perlakuan yang pengaruhnya sangat menonjol dibandingkan dengan perlakuan lainnya terhadap kadar protein tepung ikan. Hasil uji lanjut menggunakan BTN, menunjukkan bahwa semua perlakuan pada penelitian ini memiliki pengaruh yang sangat menonjol satu dengan perlakuan lainnya terhadap kadar protein tepung ikan.

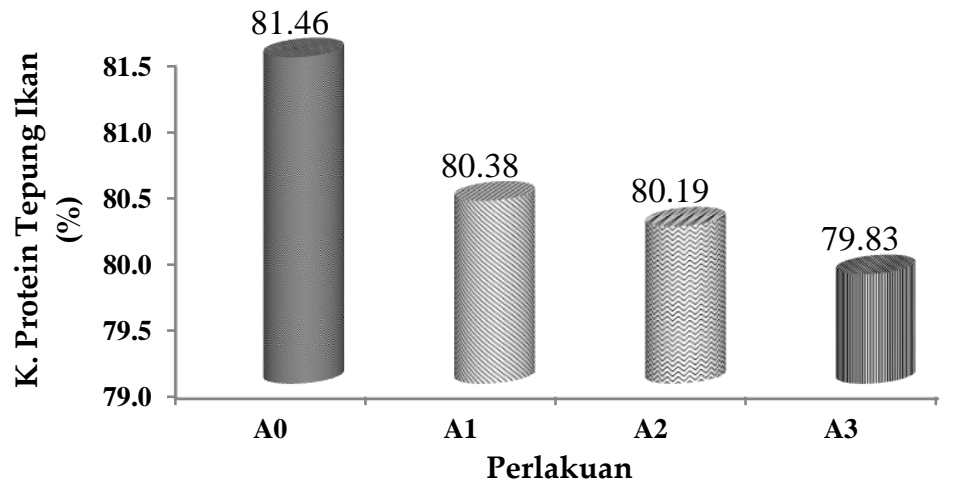

Gambar 6. Histogram Nilai Rerata Kadar Protein Tepung Ikan

d. Kadar Lemak

Hasil analisis kadar lemak pada tepung ikan tertinggi terdapat pada perlakuan $\mathrm{A}_{0}(3.84 \%)$ sedangkan kadar lemak terendah pada perlakuan $\mathrm{A}_{3}(2.47 \%)$. Perlakuan perebusan menggunakan asam asetat pada suhu tinggi mampu menghidrolisis kandungan lemak yang terdapat dalam daging merah ikan tuna. Perebusan menggunakan asam asetat pada konsentrasi yang berbeda mampu menurunkan kadar lemak, semakin tinggi konsentrasi asam asetat yang digunakan untuk perebusan semakin rendah kadar lemak tepung ikan yang dihasilkan (Gambar 7).

Kadar lemak yang lebih rendah pada tepung ikan dapat menghindari tepung ikan mengalami kemunduran mutu akibat proses ketengikan. Kadar lemak yang tinggi akan membuat tepung mudah tengik. Salah satu penyebab ketengikan tepung adalah oksidasi lemak. Suhu pengeringan yang terlalu tinggi akan menyebabkan oksidasi lemak dalam bahan pangan menjadi lebih besar dibandingkan dengan suhu pengeringan yang rendah (Mudjajanto, 1991). 


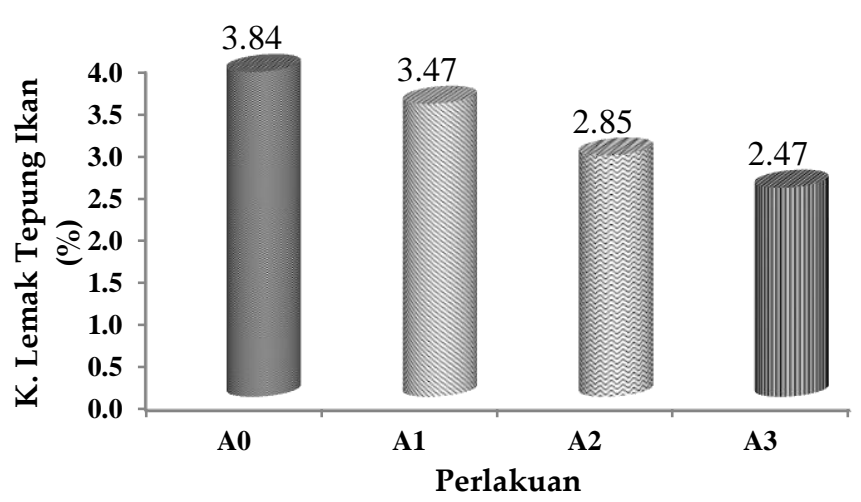

Gambar 7. Histogram Nilai Rerata Kadar Lemak Tepung Ikan

Hasil analisis sidik ragam menunjukkan bahwa konsentrasi larutan asam asetat berpengaruh sangat nyata terhadap kadar lemak tepung ikan pada $\rho>0,05$. Artinya terdapat perlakuan yang pengaruhnya sangat menonjol terhadap kontrol atu perlakukan lainnya. Hasil uji lanjut menggunakan BNT menunjukkan perlakuan konsentrasi asam asetat dalam pembuatan tepung ikan memberikan pengaruh yang nyata antar perlakuan yang diberikan. Uji Mikrobiologi ALT (Angka Lempeng Total)

Pengujian angka lempeng total (ALT) merupakan salah satu cara untuk menentukan jumlah mikroba dalam tepung ikan secara tidak langsung dengan metode hitung mikroba yang hidup dalam media. Cara ini lebih akurat dibandingkan dengan cara hitung langsung melalui pengamatan di bawah mikroskop, karena cara ini dapat menentukan jumlah mikroba hidup melalui kemampuannya membentuk koloni pada media agar yang dapat langsung dilihat dengan mata tanpa bantuan mikroskop.

Konsentrasi asam asetat pada proses perebusan mampu membunuh sejumlah mikroba yang terdapat pada daging merah ikan madidihang. Hasil ini menunjukkan bahwa tepung ikan masih memenuhi SNI tepung ikan (SNI NO 01-2332.3-2006), dengan standar minimum yang berada pada kisaran $<2500-$ 65.000 CFU/g.

\section{PENUTUP}

Perebusan daging merah ikan tuna menggunakan larutan asam asetat pada konsentrasi yang berbeda berpengaruh nyata terhadap derajat keasaman $(\mathrm{pH})$, kadar air, protein dan lemak serta derajat putih tepung ikan yang dihasilkan akan tetapi tidak berpengaruh nyata terhadap kadar abu.

Daging merah ikan madidihang dapat dijadikan bahan baku dalam pembuatan tepung ikan dan dapat di simpan dalam waktu yang lama karena memenuhi syarat sebagai bahan baku kering dari karakteristik, fisik (derajat putih), kimia (proksimat), dan mikrobiologi (ALT).

\section{DAFTAR PUSTAKA}

Amrullah. 2000. Penggunaan Imunostimulan Spirulina platensis Untuk Meningkatkan Ketahanan Tubuh Ikan Koi (Cyprinus carpio) Terhadap Virus Herpes [Tesis]. Bogor: Program Pascasarjana, Institut Pertanian Bogor

Anggawati AM. 1993 Penanganan Ikan Laut Segar. Kumpulan Hasil-Hasil Penelitian Pascapanen Perikanan. Pusat Penelitian dan Pengembangan Perikanan.

[AOAC] Association of Official Analytical Chemist. 2005. Official Methods of Analytical of The Association of Official Analytical Chemist. Washington, DC: AOAC. 
Daintith J. 2005. Kamus Lengkap Kimia, Erlangga, Jakarta. Hart, H., Craine, L. E., dan Hart, D. J., 2003, Kimia Organik: Edisi Sebelas, Erlangga, Jakarta.

Heruwati ES. 2002. Pengolahan ikan secara tradisional: prospek dan peluang pengembangan. Jurnal Litbang Pertanian.

Johnson A, Patterson MS. 1984. Encyclopedia of Food Technol Volume 2. The AVI. Publishing Co. Inc. Connecticut.

Junianto 2003. Teknik Penanganan Ikan. Seri Agriwawasan. Penebar Swadaya. Jakarta.

Learson RJ, Kaylor JD. 1990. Pelagic Fish in The Sea Food Industry. Editor. RE Martin and GJ Flick. Van Nastrand. New York.

Martinez I, Santaella M, Ros G, Periago MJ. 1998. Content and in Vitro availibility of Fe, Zn and P in homogenized fish-base weaning food after bone addition. Food Chem. 63: 299-305.

Murray ND, Michael T, Pizzorno ND. 1991. Encyclopedia of Natural Medicine. Prima Publishing, pp. 359.

Murniyati SA, Sunarman. 2000. Pendinginan, Pembekuan dan Pengawetan Ikan. Kanisius, Yogyakarta.

Okada M. 1990. Fish and Raw Material. In science of Processing Marine Food Product. Vol. I. editor. T. Motohiro, H. Kadota. K. Hashimoto. M. Katayama and T. Tokunaga. Japan International Coorporation Agency. Hyoga International Centre Japan.

Pigott GM, BW Tucker. 1990. Seafod, Effect of Technology on Nutrition. Marcel Dekker, Inc. New York. Sánchez-Zapata et al., 2011. Quality Characteristics of Dark Muscle from Yellowfin Tuna (Thunnus albacares) to Its Potential Application in the Food Industry. Food and Nutrition Sciences, 2011, 2, 22-30. doi:10.4236/ fns.2011.21003

[SNI] Standar Nasional Indonesia. SNI 01-2715-1992. Tepung Ikan.

Watanabe S. 1990. The Cemistry of protein from Marine Animals In Food Science of Processing Marine Food Product. Vol. I. Editor. T.Motohiro, H. Kadota, K. Hashimoto, M. Kayama. T, Tokunaga. Japan International Coorporation Agency. Hyoga. International Centre Japan. 